\title{
Verbs in the Essays by L2 Learners of English in Japan and the Pedagogy
}

\author{
Yoshiyuki Okaura \\ Fukuoka Institute of Technology
}

\begin{abstract}
The purpose of this research paper is to analyze and assess the textual functions and uses of verb phrases used in the essays written by 35 L2 English learners of Japanese university students from the perspective of world Englishes. First, we will analyze the textual functions and uses of five types of verbs: linking verbs, public verbs, private verbs, suasive verbs, and expecting/wanting/tentative verbs. Secondly, we will consider the frequency of the present tense and the past tense and that of the progressive aspect and the perfect aspects. Finally, we will argue that sufficient output and input is necessary for a discourse-based focus on grammar to be effective.
\end{abstract}

\section{Introduction}

The purpose of this paper is to analyze and assess the textual functions and uses of verb phrases and nouns used in the essays written by 35 L2 English learners of Japanese university students from the perspective of world Englishes, more specifically in the followings:

(1) the textual functions and uses of five types of verbs: linking verbs, public verbs, private verbs, suasive verbs, and expecting/wanting/tentative verbs [10] [11] [14] [19];

(2) the frequency of the present tense and the past tense and that of the progressive aspect and the perfect aspect;

Moreover, we will argue that L2 grammar instruction should include opportunities for learners not only to receive meaningful input but also to produce meaningful output in order for a discoursebased focus on grammar to be effectively taught, even though there is some restrictions by the entrance examinations for universities in Japan.

\section{Procedures}

\subsection{Designing questionnaire and writing assessment task}

In order to investigate the characteristics of L2 English leaners of Japanese university students, we constructed the whole questionnaire in English, which is composed of general information, multiplechoice items, rank order items, and the writing assessment task. First, the half part of the questionnaire is composed of the questions about the learning

Secondly, the writing assessment tasks were designed on the basis of Cumming and Okaura [1] [2] [3] [4] [17]. Cumming suggests that skilled multilingual writes tend to use their first or dominant language (L1) frequently, extensively, and effectively while they compose in a second language (L2) [1] [2]. Cumming also points out that they do so in episodes of mental decision making that I have called heuristic search strategies because they help writes systematically solve problems they encounter when formulating or editing their written texts [4]. Moreover, the writing assessment task conducted in Okaura was as follows [17]:

(4) Please write an English essay in one paragraph to explain three most important aspects of Japanese culture to people in other countries without using dictionaries or asking your teacher for advice. The time limit is 40 minutes.

The writing assessment task in (4) was partly worked well, but it partly did not. That is to say that some students couldn't write many words because they had little knowledge of the words and phrases to express their ideas in English, even though they have sufficient time allotted to the writing assessment task.

Therefore, we revised and improved the writing assessment task for this current research. Considering heuristic search strategies, we adopted the combination of the timed in-class writing assessment tasks in (6) and (7), so-called linked assignments [6]. Cumming insists that heuristic search strategies involving language switching for choices of words and phrases while composing help writers systematically solve problems they encounter when formulating or editing their written texts [3] [4]. Thus we combined the writing assessment task in (6) with that in (7), to facilitate heuristic search strategies:

(6) Please write an English essay about "My Favorite Thing(s)" in 100-200 words without using your dictionaries or asking your teacher and classmates for advice. The time limit is 20 
minutes.

(7) Please write an English essay about "My Favorite Thing(s)" in 100-200 words. You can use the word list for reference but cannot use your dictionaries or ask your teacher and classmates for advice. The time limit is 20 minutes.

As described in (7), the word list was introduced in order to help L2 English learners of Japanese university students write more words per essay. This is because Weigle insists that the introduction of the word list will also lead to more words per essay, which is provided as a stimulus material [20]. Therefore, we decided to introduce "The General Service List," which the respondents can refer to while they are working on the writing assessment task, and which I expect will work better than "The Academic Word List" [13].

\subsection{Data collection}

We collected the data of the writing in the classroom of the Faculty of Pharmaceutics at A University (anonymous). Okaura collected data through the email; first, Okaura sent an email message with the attached file to a teacher working at a university in Japan; she emailed it to the students of three classes; then the students filled in the blanks of the questionnaire and wrote an English essay; and finally they sent it to me by email [15] [16]. This way of collecting data mostly worked well, but there was some trouble with the Internet. The current research employed another way of collecting data in order to prevent such a problem from happening. This means that we conducted the questionnaire and writing assessment tasks in class so that we could surely collect data.

The number of the students who signed up for my English course was 35, and the total number of the respondents is also the same. All of them entered the university just one month ago. There was no problem happening in collecting data for this research. The number of words used in the essays in (7) is 4,130 in total, in which respondents can use the word list. This means that the average number of the words that the respondents wrote in order to explain "My Favorite Thing(s)" is 118 words per essay.

\section{Discussion}

In this chapter, we will mainly analyze the verbs, and also the nouns used in the essays written by L2 English learners of Japanese university students.
Kirkpatrick insists that a native speaker model is disadvantageous, not only because it is unattainable, but also because it is inappropriate for all but a minority of students [10]. Moreover, Okaura suggests that it is very difficult to clarify the borders between acceptability and unacceptability from the perspective of World Englishes [15] [16]. Furthermore, as Honnna points out, standards of acceptability and correctness are not absolute but variable and negotiable, and that the bottom line is mutual intelligibility and communicability [9]. Okaura proposes that the characteristics affected by the Japanese language or features of Japanese English are acceptable as English of L2 learners from the point of view of optimal relevance and explicature in the framework of Relevance Theory, which is an approach to the field of pragmatics originated by Sperber \& Wilson [15] [16] [18].

This is closely related to the difference between global errors and local errors. Local errors do not impede comprehension but global errors cause a reader to misunderstand what the author is trying to say. It is important for student writers to correct global errors and less important to correct local errors. On the other hand, local errors like subjectverb agreement or verb tense problems might be things that subject matter teachers find annoying so that they affect their grading of students, as Birch points out. Therefore, we put less emphasis on local errors and the analysis of errors, and hence this paper will deal with the characteristics of L2 learners of Japanese students observed in the essays. Therefore, we will not go into the details of local errors such as third person singular present suffix $-\mathrm{s}$, plural noun suffix $-s$, the definite articles and the indefinite articles, misspelling, and so forth in this paper.

Table 1. Features with significantly higher median frequency rates in NNS and NS texts

\begin{tabular}{|l|l|}
\hline $\begin{array}{l}\text { Interpretive } \\
\text { nouns }\end{array}$ & Predicative adjectives \\
\hline Vague nouns & Amplifiers \\
\hline $\begin{array}{l}\text { Assertive } \\
\text { pronouns }\end{array}$ & Other adverbs \\
\hline Public verbs & Adverb clauses of cause \\
\hline Private verbs & $\begin{array}{l}\text { Phrasal-level } \\
\text { conjunctions }\end{array}$ \\
\hline $\begin{array}{l}\text { Expecting/ } \\
\text { tentative verbs }\end{array}$ & $\begin{array}{l}\text { Sentence-level } \\
\text { conjunctions(transitions) }\end{array}$ \\
\hline $\begin{array}{l}\text { Modal verbs of } \\
\text { necessity }\end{array}$ & $\begin{array}{l}\text { Exemplification markers } \\
\text { (for example) }\end{array}$ \\
\hline $\begin{array}{l}\text { Be as a main } \\
\text { verb }\end{array}$ & Emphatics \\
\hline
\end{tabular}


Hinkel summarizes findings for NS (native speaker) and NNS (non-native speaker) data in broad strokes [7]. Table 1 enumerates the features with NNS median frequency rates significantly greater than those in NS text across all L1 groups.

On the other hand, Table 2 presents the features with NNS median frequency rates significantly lower than those in NS text across all L1 groups:

Table 2. Features with significantly lower median frequency rates in NNS and NS texts

\begin{tabular}{|l|l|}
\hline It-cleft & Present participles \\
\hline Perfect aspect & Past participles \\
\hline Progressive aspect & $\begin{array}{l}\text { Reduced adjective } \\
\text { clauses }\end{array}$ \\
\hline $\begin{array}{l}\text { Predictive modal } \\
\text { would }\end{array}$ & $\begin{array}{l}\text { Reduced adverb } \\
\text { clauses }\end{array}$ \\
\hline Passive voice & $\begin{array}{l}\text { Fixed strings } \\
\text { (idiomatic phrases } \\
\text { and collocations) }\end{array}$ \\
\hline
\end{tabular}

Then, we will deal with the functions and usages of five types of verbs in the essays written by L2 learners of Japanese students. The total number of the verbs used in the essays amounts to 869 of 4,130 words. We will divide these verbs into five types and the others and analyze them: that is to say, linking verbs, public verbs, private verbs, suasive verbs, and expecting/wanting/tentative verbs.

Linking verbs accounted for $25.6 \%$. The function of the verb the second most frequently used of the five was private verbs such as feel, find, forget, hear, know, learn, listen, see, think, and understand, which accounted for $14.2 \%$. Moreover, the use of expecting/wanting/tentative verbs accounted for $12.4 \%$.

On the other hand, the use of public verbs was quite limited to some basic ones such as say, tell, and write $(3.7 \%)$. The use of suasive verbs was also quite limited; only verbs such as ask, encourage, and recommend are used, accounting for no more than $0.05 \%$

Table 3. Five types of verbs

\begin{tabular}{|c|c|c|c|}
\hline & $\begin{array}{c}\text { Linking } \\
\text { verb }\end{array}$ & $\begin{array}{c}\text { Public } \\
\text { verb }\end{array}$ & $\begin{array}{c}\text { Private } \\
\text { verb }\end{array}$ \\
\hline $\begin{array}{c}\text { Total } \\
\text { number }\end{array}$ & 222 & 32 & 123 \\
\hline$\%$ & 25.60 & 3.70 & 14.20 \\
\hline & $\begin{array}{c}\text { Suasive } \\
\text { verb }\end{array}$ & $\begin{array}{c}\text { Expecting } \\
\text { verb }\end{array}$ & $\begin{array}{c}\text { Other } \\
\text { verbs }\end{array}$ \\
\hline $\begin{array}{c}\text { Total } \\
\text { number }\end{array}$ & 4 & 108 & 380 \\
\hline$\%$ & 0.05 & 12.40 & 43.70 \\
\hline
\end{tabular}

We will go into the details of each verb type. First, only three kinds of linking verbs are used in the essays: be, become, and sound. The number of examples of linking verbs amounts to 222 in total. Moreover, all of the 35 respondents used linking verb be at least twice in the essays, and the reason for this is that the title of the writing assessment tasks is "My Favorite Thing(s)" and that all the 35 respondents use the sentence beginning with "My favorite thing is" or " My favorite things are." The L2 writers used the linking verb be with predicative adjectives and made statements that were simplistic and not dense or complex. The total number of the linking verb be used in the 35 essays is 216 , as is shown in Table 4 below, which means that the total number of the use of be accounts for $24.86 \%$, and that the average number of be used in each essay is 6.17 .

Table 4. Linking verbs

\begin{tabular}{|c|c|c|c|}
\hline & be & become & sound \\
\hline $\begin{array}{c}\text { Total } \\
\text { number }\end{array}$ & 216 & 7 & 1 \\
\hline$\%$ & 24.86 & 0.81 & 0.12 \\
\hline
\end{tabular}

We will cite an essay in which the use of the linking verb $b e$ is characteristic. Example 1 below is an exactly 100-word essay, in which be are used no fewer than twelve times.

Example 1. The essay written by Student AE

I like music very much. I listen to music every day. My favorite singer are "miwa" and "Good Coming." Miwa is a Japanese singer. She is very cute. Her voice is nice. I think that the best song of hers is "Jexxxa." This song is mixed her voice and guiter. Good Coming is a Japanese band. It makes two person who are vocal and guiter. They are always kind to funs. Their songs makes me happy and moving every day. "Nakama" is their song which is notice importance of friendship. "Birdman" is also their song which makes me always excited.

Next, we will consider the use of public verbs in the essays. Public verbs consist of speech act verbs introducing indirect statements, and they are also used for introducing direct speech [19]. They accounts for $3.70 \%$ of the total use of verbs in the essays, and the number of its use is only 32 in total. Furthermore, only 6 kinds of public verbs are used in the essays: express, say, sing, tell, talk, and write, as shown in Table 5: 
Table 5. Public verbs

\begin{tabular}{|c|c|c|c|}
\hline & express & say & sing \\
\hline $\begin{array}{c}\text { Total } \\
\text { number }\end{array}$ & 2 & 2 & 10 \\
\hline$\%$ & 0.23 & 0.23 & 1.15 \\
\hline
\end{tabular}

\begin{tabular}{|c|c|c|}
\hline tell & talk & write \\
\hline 3 & 14 & 1 \\
\hline 0.35 & 1.61 & 0.12 \\
\hline
\end{tabular}

The verb talk is most frequently used of the six public verbs, the reason for which is that the title of the essay the students worked on is "My Favorite Thing(s)" which they want to talk about. Here is the example in which the public verb talk is most frequently used:

Example 2. The essay written by Student $\mathrm{Z}$

My favorite thing is talking with my friend and family. I have three reasons. First, I can always enjoy talking with them. They always talk funny things to me. Especially I like to talk about fashion and clothes the best. They teach information which I don't know. Second, even if I don't feel good, they always make me fun. So I can forget things which I don't want to think. Third, they always give me good advice when I have a trouble. Their advice is the best. If I think a trouble by alone, I'm not able to come up with a good advice. So I always thank for them. Thus, I like to talk with my friend and family.

In this 120-word essay, the public verb talk is used five times in total. Moreover, this example includes such private verbs as feel, forget, know, and think.

Private verbs are the type of factual verb and express intellectual states such as belief and intellectual acts such as discovery [19]. Hinkel states that in both non-native speaker texts, the frequency rates of private verb uses greatly exceeded those of public verbs, particularly in the case of native speakers [7]. In the essays written by L2 English learner of Japanese university students, private verbs are the most frequently used second to linking verbs and more frequently used than public verbs, as is obvious from Table 3 .

We found out that they are used 123 times in total, and the 17 kinds of private verbs are used in the 35 essays. The private verb most frequently used is feel. Furthermore, listen, read, and think are also used frequently, and the think is especially the private verb which not only L2 English learner of Japanese university students but also junior high school students and senior high school students in Japan are most likely to use both in writing and speaking English. In fact, they tend to use the private verb think too much frequently, because they will of course express their ideas and thoughts in the writing and speaking English. For the detailed use of private verbs, see Table 6 below:

Table 6. Private verbs

\begin{tabular}{|c|c|c|c|}
\hline & check & feel & find \\
\hline $\begin{array}{c}\text { Total } \\
\text { number }\end{array}$ & 3 & 20 & 3 \\
\hline$\%$ & 0.35 & 2.30 & 0.35 \\
\hline
\end{tabular}

\begin{tabular}{|c|c|c|c|}
\hline forget & hear & hope & imagine \\
\hline 3 & 7 & 2 & 1 \\
\hline 0.35 & 0.81 & 0.23 & 0.12 \\
\hline
\end{tabular}

\begin{tabular}{|c|c|c|c|}
\hline know & learn & listen & notice \\
\hline 8 & 5 & 13 & 1 \\
\hline 0.92 & 0.58 & 1.50 & 0.12 \\
\hline
\end{tabular}

\begin{tabular}{|c|c|c|c|}
\hline see & read & remember & think \\
\hline 9 & 12 & 1 & 12 \\
\hline 1.04 & 1.38 & 0.12 & 1.38 \\
\hline
\end{tabular}

\begin{tabular}{|c|c|}
\hline understand & watch \\
\hline 3 & 20 \\
\hline 0.35 & 2.30 \\
\hline
\end{tabular}

We will cite the essays here in which private verbs are prominently used:

Example 3. The essay written by Student W

My favorite thing is Ice Hockey. There are two reasons for this.

First, when I watch the sport, I feel moving and exciting. When I was five years old, I went to Canada with my family. Canada is one of famous countries by Ice Hockey. Thus, my mother said that we should see the sport. At that time, I didn't know the sport and I disagreed with it. However, when I saw the sport games, I couldn't see it without exciting. Thus, Ice Hockey games are so great.

Second, when I play the sport, I feel very fun and exciting. After I saw the game in Canada, I've played Ice Hockey for twelve years. Since I played it first, I've never felt the sport was boring or not good. I can play it with smile and try hard.

For those reasons, I like... love Ice Hockey and I can't imagine without Ice Hockey life!!

Table 7. Private verb uses in Example 3

\begin{tabular}{|c|c|c|c|}
\hline & feel & imagine & know \\
\hline $\begin{array}{c}\text { Total } \\
\text { number }\end{array}$ & 3 & 1 & 1 \\
\hline
\end{tabular}

\begin{tabular}{|c|c|}
\hline see & watch \\
\hline 4 & 1 \\
\hline
\end{tabular}


In this 154-word essay in Example 3, the private verbs are used ten times in total, as is shown in Table 7.

Moreover, expecting/wanting/tentative verbs are used three times in Example 3: like, love, and try.108 examples of expecting/wanting/tentative verbs can be observed in the essays written by the 35 L2 English learners of Japanese university students, and their use accounts for $12.40 \%$ of all the verbs.

Table 8. Expecting/wanting/tentative verbs

\begin{tabular}{|c|c|c|c|}
\hline & hate & like & love \\
\hline $\begin{array}{c}\text { Total } \\
\text { number }\end{array}$ & 3 & 60 & 13 \\
\hline$\%$ & 0.35 & 6.90 & 1.50 \\
\hline
\end{tabular}

\begin{tabular}{|c|c|}
\hline try & want \\
\hline 4 & 28 \\
\hline 0.46 & 3.22 \\
\hline
\end{tabular}

One characteristic of expecting/wanting/tentative verbs is that the use of like amounts to $6.90 \%$ of all the verbs, and that it accounts for no fewer than $55.6 \%$ of all the expecting/wanting/tentative verbs. It is clear that this is closely related to the title of the writing assessment tasks which 35 respondents worked on, "My Favorite Thing(s)." Another characteristic is that want is used 28 times in total, but that wish is not used at all, although they learn both want and wish along with infinitives and the subjunctive mood at junior and senior high schools in Japan and the meanings of both verbs are almost the same.

Example 4 shows the characteristics that the expecting/wanting/tentative verb like is used seven times and that the linking verbs are used 8 times:

Example 4. The essay written by Student Q My favorite thing is my pet named "Muffin." He is cat. His kind is British short. He is one years old. His color is bright brown. He likes food. He eats cat food at seven a.m. and seven p.m. he cry before 7 everytime. He likes ball. He plays with it. He likes my mother too. He follows her everytimes. He doesn't like big noise. If he heard big noise, he ran and he goes to under the sofa. He also doesn't like my pufume.

I like him very much so I take a picture of him so much. He is more cute than any other cat. His eyes are like juwery. His hands are very soft. My family also like him very much. I want him to sit on my leg. But he doesn't.

This example consists of 135 words, and includes some local errors: for example, in the third person singular present $-s$, countable nouns or uncountable nouns, singular nouns or plural nouns, the spelling of the words. However, this paper will not deal with these errors.

The example below indicates that the linking verb be, private verb feel, and expecting/wanting/tentative verb like are used frequently:

Example 5. The essay written by Student $\mathrm{T}$ I like food. My favorite food is "ebifurai" and sweets, sushi. Eating my favorite food feel me happy and forget bad things. Especially, I like sweets very much. Sweets are very cute and have a lot of kinds/ girls like sweets because sweets shops are very cute or beautiful. I feel happy when I eat cake and tea in Afternoon tea. And I like cooking sweets. But cooking sweets is very difficult so I cook easy sweets. I feel happy even when I cook sweets. I think sweets are very perfect. Just no sweets no life. Eating your favorite food is very good think, feel you happy. But don't eat that too much because you will may be fat. I recommend you that you eat your favorite food when you feel sad and negative. That can change you. That's all. Thank you.

This 142-word essay includes eight uses of linking verb $b e$, five of private verb feel, and also four of expecting/wanting/tentative verb like.

Suasive verbs can be followed by a that-clause either with should or with the mandative subjunctive, and, though largely restricted to British English, by a that-clause with an indicative verb [19]. As is clear from Table 3, the use of suasive verbs extremely limited to only the three verbs: allow, decide, and recommend.

Next, we will discuss the results of the tenses, aspects, the infinitives or gerunds used in the essays written by L2 English learners in Japan. If we divide the total use of finite verbs into the present tense and the past tense, the results are as follows:

Table 9. Use of present tense and past tense

\begin{tabular}{|c|c|c|}
\hline & $\begin{array}{c}\text { Present } \\
\text { tense }\end{array}$ & Past tense \\
\hline Total number & 502 & 139 \\
\hline$\%$ & 78.30 & 21.70 \\
\hline
\end{tabular}

Table 9 shows the overwhelmingly frequent uses of the present tense, accounting for $78.3 \%$ of the total uses of finite verbs.

Hinkel argues that although in research on the acquisition of tenses and tense inflections, the progressive aspect in the present tense has been noted as relatively easy for NNSs, in the NNS essays, the issue of progressive aspect use is not so 
much the acquisition of this aspect as it is contextual meanings uses in academic text [7]. She also mentions that the majority of NNSs did not use the progressive aspect a great deal, which differed significantly from the frequency rates of NSs. This applies to the result of the current research, which means that only 3 examples of the progressive aspects can be observed, and 12 of the past aspects can, as is shown in Table 10:

Table 10. Use of progressive aspect and perfect aspect

\begin{tabular}{|c|c|c|}
\hline & $\begin{array}{c}\text { Progressive } \\
\text { aspect }\end{array}$ & $\begin{array}{c}\text { Perfect } \\
\text { aspect }\end{array}$ \\
\hline Total number & 3 & 12 \\
\hline$\%$ & 20.00 & 80.00 \\
\hline
\end{tabular}

In general, the perfect aspect and the passive voice constructions are hard for NNSs to acquire and use in appropriate contexts, and they avoided using them in the texts they wrote (14). In addition, we can say that the progressive aspect is very hard for L2 learners of Japanese university students, as is shown in Table 3.

Table 11 shows that the infinitives accounted for $12.36 \%$, and the gerunds $7.62 \%$ :

Table 11. Use of infinitive and gerund

\begin{tabular}{|c|c|c|}
\hline & Infinitive & Gerund \\
\hline Total number & 99 & 61 \\
\hline$\%$ & 61.90 & 38.10 \\
\hline
\end{tabular}

Here is the example in which 9 infinitives and 4 gerunds are used:

Example 6. The essay written by Student $\mathrm{P}$

I like to play tennis. When I was 10 years old, I played tennis at the first time. I was not able to play tennis very well, but I enjoyed playing. I belonged to tennis club in junior high school, because I love tennis. I was glad to play tennis. But I couldn't play every day. I was made to run every day teacher said "Run and you will be strong!" I regretted to belong to tennis club. In high school, I didn't belong to any club. I love tennis but I hate training. I didn't want to run any more! Now, I'm 19 years old and college student. I decided to join "Squall." "Squall" is tennis club. They love tennis and enjoy playing it. And they didn't make me to run! I'm happy to enjoy plaving tennis.

The author of this 138-word essay makes use of both infinitives and gerunds. Especially, some usages of infinitives can be observed in this essay: causative verb make, both the active voice and the passive voice, followed by the infinitive, adjectives able, glad, and happy followed by the infinitives, and other usages.

\section{Suggestions}

In this paper, L2 English learners of Japanese university students used only limited verb phrases and noun phrases, namely linking verbs and expecting/wanting/tentative verbs, and vague nouns, although they learned many more verb phrases and noun phrases in junior and senior high schools in Japan.

In Japan, students have to learn 2,000 English words on average before graduating from high school. Moreover, students who try to go on to one of the most prestigious universities have to learn more than 5,000 words; in fact, their meanings, but not their usages. That is because they do not have enough opportunities to use words they learned actively in writing and speaking.

Ferris points out that L2 readers and writers in academic settings are well aware that they lack an adequate English vocabulary, and that it may thus be enlightening to them to learn that there are different general types of vocabulary and that certain words tend to occur frequently or infrequently in different types of texts [6]. Furthermore, Nassaji \& Fotos insists that it is now acknowledged that learners need to acquire chunks of speech, formulaic utterances, and frequently occurring collocations through communicative usage [12]. Therefore we introduced "The General Service List" as a stimulus material, which L2 learners of English can refer to while they are working on the writing assessment task. This helped them produce meaningful output and promoted them to write more words per essay.

Hyland notes that advanced L2 writers are handicapped more by a lack of composing competence than linguistic competence. The opposite is true for lower-proficiency learners. It is now widely acknowledged, as Nassaji \& Fotos suggests, that formal instruction on grammar forms is necessary to promote L2 learner accuracy and high levels of target language attainment [12]. Thus, it is now recognized that it is essential to make the target language structure obvious to the learner, whether through formal instruction or through manipulation of communicative input, in ways that call attention to target forms and allow learners to process them, or a combination of these methods [12].

Based on the recognition, Nassaji \& Fotos insists on the need for a discourse-based focus on grammar [12]. They propose that L2 grammar instruction, either explicit or implicit, should take place in extended contexts rather than in isolation, and should include opportunities for learners to receive 
meaningful input and to produce meaningful output containing the target form, because only discourselevel input can provide learners with repeated authentic examples of these important forms and only discourse-level output can give learners the necessary chances to produce the new forms.

Furthermore, Hinkel demonstrates that the contextualized teaching of grammar can expose learners to ways in which language is used in real life and heighten their awareness of its conventions and complexities [8]. She insists that it is important to supplement the explanations with ample practice to allow leaners to produce writing.

In Japan, the entrance examinations for universities have effects on the teaching of English writing in senior and junior high schools. Most of the private universities in Japan receive a lot of applicants every year, but they have only about one week before the announcement of successful applicants. This is not enough for universities to impose writing English essays in the entrance examinations on their applicants. As for the national universities, the applicants usually have to take two examinations: the National Center University Entrance Examination and then the examinations held by each national university. The National Center University Entrance Examination, for which 573,344 applicants of $1,092,543$ prospective graduates applied in 2013 academic year, employs multiple-choice form in all questions. That is to say, even if L2 grammar instruction should include opportunities for learners to receive meaningful input, they suffer from the lack of opportunities to produce meaningful output in English education system in Japan. This is true of the applicants for admission to both national universities and private universities, because the primary purpose is to pass the entrance examinations for universities. It is crucial that we should provide L2 English learners with the sufficient opportunities for output and input, because only discourse-level input can provide learners with repeated authentic examples of the new forms and because only discourse-level output can give learners the necessary chances to produce them.

\section{Acknowledgements}

This research was partly supported by JSPS KAKENHI Grant Numbers 22720227.

\section{References}

[1] Cumming, A. (1989). Writing Expertise and Second Language Proficiency. Language Learning, 39, 81-141.
[2] Cumming, A. (1990). Metalinguistic and Ideational Thinking in Second Language Composing. Written Communication, 7, 482-511.

[3] Cumming, A. (2010). "Theories, Frameworks, and Heuristics: Some Reflections on Inquiry and Second Language Writing.” In Silva, T., \& Matsuda, P. K. (Eds.), Practicing Theory in Second Language Writing (pp. 19-47). Indiana: Parlor Press.

[4] Cumming, A. (2013). "Multiple Dimensions of Academic Language and Literacy Development." Language Learning 63, 1, 130-152.

[5] Dornyei, Z. (2007). Research Methods in Applied Linguistics. Oxford: Oxford University Press.

[6] Ferris, D. N. (2009). Teaching College Writing to Diverse Student populations. Michigan: The University of Michigan Press.

[7] Hinkel, E. (2002a). Second Language Writers' Text: Linguistic and Rhetorical Features. New York: Routledge.

[8] Hinkel, E. (2002b). "Teaching Grammar in Writing Classes: Tenses and Cohesion." In Hinkel, E., \& Fotos, S. (Eds.), New Perspectives on Grammar Teaching in Second Language Classrooms, 181-198. New York: Routledge.

[9] Honna, N. (2008). English as a Multicultural Language in Asian Contexts: Issues and Ideas. Tokyo: Kuroshio Publishers.

[10] Kirkpatrick, A. (2007). World Englishes: Implications for International Communication and English Language Teaching. Cambridge: Cambridge University Press.

[11] McKay, S. L. (2002). Teaching English as an International Language. Oxford: Oxford University Press.

[12] Nassaji, H., \& Fotos, S. (2011). Teaching Grammar in Second Language Classrooms: Integrating Form-Focused Instruction in Communicative Context. New York: Routledge.

[13] Nation, I. S. P. (2008). Teaching Vocabulary: Strategies and Techniques. Massachusetts: Heinle, Cengage Learning.

[14] Nelson, C. L. (2011). Intelligibility in World Englishes: Theory and Application. New York: Routledge.

[15] Okaura, Y. (2009a). "Relevance-Theoretic Approach to Some Characteristic Grammatical Constructions and Usages in 50-Word Essays by Japanese Students." Asian Englishes, 11, 2, 46-63.

[16] Okaura, Y. (2009b). "Grammatical Characteristics of Good 50-Word Essays by Japanese Students of English: Optimal Relevance through the Formation of Explicatures. Intercultural Communication Studies, 18, 2, 214-228. 
[17] Okaura, Y. (2011). English Grammatical Construction of L2 Japanese University Students and Pedagogical Grammar for English in Japan. In The Proceedings of 2011 JACET 50th Memorial International Convention.

[18] Sperber, D., \& Wilson, D. (1995). Relevance Theory: Communication and Cognition. New York: Blackwell. (Original work published in 1986)

[19] Quirk, R., Greenbam, S., Leech, G., \& Svartvik, J. (1985). A Comprehensive Grammar of the English Language. New York: Longman.

[20] Weigle, S. C. (2002). Assessing Writing. Cambridge: Cambridge University Press. 